\title{
ECHOVIRUS 19 INFECTION IN ADULTS AND CHILDREN A CONTRAST
}

\author{
Major P. LYNCH, M.B., M.R.C.P., R.A.M.C. \\ Lieutenant-Colonel B. SIMPSON, M.B., M.R.C.P.(Ed.), R.A.M.C. \\ Lieutenant-Colonel J. C. WILSON, M.B., M.R.C.P., D.C.H., R.A.M.C. \\ British Military Hospital; Munster \\ DIANE CRONIN, B.Sc. \\ Colonel E. E. VELLA, M.D., F.R.C.Path. \\ Royal Army Medical College, Millbank
}

SUMMARY: During an outbreak of Echovirus type 19 infection in a British military community in West Germany, serious illness was commoner in adults than in children. Bornholm disease and aseptic meningitis were the dominant features, the former being seen only in adults. Myopericarditis was suspected in one man. Contemporary outbreaks in Britain, West Germany and the British military community in West Germany, may illustrate the role of the latter as one of the transmitters of infection between the two countries.

\section{Introduction}

Echovirus type 19 (Echo 19) was first isolated from the faeces of a child with diarrhoea in 1955 (Ramos-Alvarez and Sabin 1958) and from the cerebrospinal fluid (c.s.f.) of a man with aseptic meningitis in 1959 (Faulkener and Ozere 1960). Minor epidemics have been reported usually of upper respiratory tract infection in children (Crovari 1969). In 1974 and 1975 occurred the largest epidemic of Echo 19 infection yet recorded in Britain; most of the reported cases were infants and children and aseptic meningitis was common (Communicable Disease Reports 1974 and 1975). Simultaneous outbreaks occurred in British military communities in the North of the Federal Republic of West Germany, affected adults being almost as numerous as children (Robertson 1976). Grist, Bell and Reid (1975) suggested that, as with polioviruses, the other enteroviruses may increasingly affect adults, with clinical manifestations that differ from those seen in children. Relevant to this view are our findings in patients who were admitted to the British Military Hospital, Munster, with Echo 19 infection between July and September 1974. Bornholm disease and aseptic meningitis were the main presentations in adults. In children serious illness was rarer, and Bornholm disease was not seen. Epidemic serious illness in adults, and largely confined to adults, has not been noted in Echo 19 infection prior to this outbreak.

\section{Methods}

Virus was identified by isolation from specimens of c.s.f. or faeces in monkey kidney and human epithelial type 2 tissue culture cells, and/or by specific serum neutralisation tests. 
Adults

Details of the adult cases are shown in Table I. All were married.

Table I

Details of adult cases

\begin{tabular}{c|c|c|c|c|c|c|c|c}
\hline Patient & Age & Sex & $\begin{array}{c}\text { (a) } \\
\text { Bornholm } \\
\text { disease }\end{array}$ & Meningism & $\begin{array}{c}\text { (b) } \\
\text { c.s.f. } \\
\text { lymphocytes } \\
/ \mathrm{mm}^{3}\end{array}$ & $\begin{array}{c}\text { c.s.f. } \\
\text { protein } \\
\text { mg/100 ml }\end{array}$ & $\begin{array}{c}\text { Echo 19 } \\
\text { isolation }\end{array}$ & $\begin{array}{c}\text { (c) } \\
\text { Titres }\end{array}$ \\
\hline 1 & 27 & $\mathrm{M}$ & + & & & & & $1 / 801 / 80$ \\
\hline 2 & 28 & $\mathrm{M}$ & + & + & 30 & 40 & c.s.f. & $1 / 201 / 20$ \\
\hline 3 & 25 & $\mathrm{M}$ & Pneumonia & & & & & $1 / 401 / 160$ \\
\hline 4 & 27 & $\mathrm{M}$ & + & & & & & $<1 / 160<1 / 160$ \\
\hline 5 & 28 & $\mathrm{M}$ & & + & 170 & 90 & c.s.f. & \\
\hline 6 & 28 & $\mathrm{M}$ & + & + & 85 & 35 & & $1 / 401 / 80$ \\
\hline 7 & 22 & $\mathrm{~F}$ & & + & 5 & 30 & c.s.f. & \\
\hline 8 & 28 & $\mathrm{~F}$ & & + & Bloody tap & & Faeces & $<1 / 401 / 80$ \\
\hline 9 & 30 & $\mathrm{~F}$ & $\begin{array}{c}\text { Generalised } \\
\text { myalgia }\end{array}$ & & & & & $<1 / 1601 / 160$ \\
\hline
\end{tabular}

Notes: (a) Abdominal pain and tenderness, and intercostal myalgia. (b) c.s.f. sugar content was 52-70 $\mathrm{mg} / 100 \mathrm{ml}$. (c) Paired sera collected at intervals of about 10 days; it is realised that some are not diagnostic and Echo 19 infection was diagnosed on the combination of clinical features, time of presentation, isolation of virus and sera which showed any neutralisation effect on Echo 19 virus.

Blood white cell and differential counts were normal in all patients.

The typical body temperature was $38^{\circ} \mathrm{C}$ and it settled to normal in five days. There was a delay of four to five days between the onset of illness and the appearance of meningism, as is characteristic in enteroviral infection.

No patient had a pleural rub. No pathogenic bacteria were isolated from sputum. Patient number 3 presented with right lower lobe pneumonia, the radiological appearances favouring a bacterial aetiology; he had a non-specific rash attributed to aspirin.

Electrocardiograms were recorded in three patients who complained of praecordial pain. In two the tracings were normal, the third was Patient number 2 described below. Patients numbers 5 and 9 had loose motions. Patient number 7 was eighteen weeks' pregnant and has since been delivered of a normal full-term infant. Specimens of liquor amnii, cord blood and placenta did not provide evidence of Echo 19 infection.

Patient number 2 exemplifies the clinical findings: on 17 August 1974 a male medical orderly developed fever $\left(39^{\circ} \mathrm{F}\right)$ and severe upper abdominal pain which spread by the next day to involve the left anterior chest, was constant and gripping, and was exacerbated by movement and respiration. When admitted that evening he was acutely tender in the upper abdomen. Chest X-ray showed a small opacity at the left lung base with pleural reaction. Electrocardiograms showed ST elevation of $1 \mathrm{~mm}$, concave upwards, in leads 1, 2, aVf and $\mathrm{V}_{5-6}$, and ST depression in aVr; blood levels of AsT and LDH were normal and at no time was a perocardial rub heard. On 21 August he developed 
increasing neck stiffness; c.s.f. showed aseptic meningitis and Echo 19 was isolated. A week later he was sympton-free. Chest X-ray cleared in five weeks. Electrocardiograms remained unaltered over five weeks.

Eight other patients, three married women and five men, were admitted with clinical features suggestive of Echo 19 infection, in whom virological studies were not performed. Six had severe febrile headache; the c.s.f. was examined in two and showed aseptic meningitis. Two showed the features of Bornholm disease.

\section{Children}

There was a rise in the number of children seen by general practitioners in our area from the end of June to the beginning of August 1974; most presented with respiratory infections. This increase was not reflected in the number of admissions to the hospital's paediatric unit. One child was admitted with aseptic meningitis $\left(7\right.$ lymphocytes $/ \mathrm{mm}^{3}$ c.s.f.) and the c.s.f. of another was examined with normal results. One other child presented with severe febrile headache. Three were admitted with features suggestive of mesenteric adenitis but none resembled the adults with Bornholm disease. The children were between two and ten years old. Virological studies were not performed.

\section{Munster}

Eight patients from the civilian population, two of whom were children, were reported by the virological institute in Munster as cases of Echo 19 infection during the time of the military outbreak. Most had aseptic meningitis.

\section{Discussion}

Our finding of a predominance of serious illness in adults during the outbreak of Echo 19 infection supports Grist, Bell and Reid's (1975) suggestion that enteroviruses may increasingly affect older age groups. Further, the occurrence of Bornholm disease in adults alone is in keeping with their comment that the clinical features of infection may differ from those seen in children; perhaps differences in immune responsiveness with age are responsible (Grist, Bell and Reid 1975). It is also of interest that an outbreak of aseptic meningitis in the British service community in Hong Kong in 1960, due mainly to Coxsackie B strains, was largely confined to adults, while in the following year, when Coxsackie A9 was mainly responsible, eighteen of twenty-one patients were children (Hughes et al 1963). Perhaps enteroviruses vary in their selectivity for different age groups independently of host immune status, and this is a factor in the production of varying patterns of illness.

In one patient the clinical picture and initial electrocardiograms were suggestive of myopericarditis but the lack of change in serial recordings made the diagnosis doubtful, and we cannot add to Bell and Grist's (1970) description of this complication.

Thousands of servicemen and their families who are stationed in West Germany are in regular contact with Britain, through leave visits and postings, and with the German population through shopping and entertainment. It is possible in view of the simultaneous outbreaks of Echo 19 infection in the two countries and in the service communities, that the latter form a route for the transmission of infection, along with tourists, businessmen, and airline, ship and lorry crews. 


\section{Acknowledgements}

We are grateful to Professor Dr. G. M. Maass of the Institut für Virusdiagnostik, Munster, for permission to quote his findings, to Captain B. Robertson, R.A.M.C. for permission to refer to his paper, to Lieutenant-Colonel Kilpatrick, M.R.C.G.P., R.A.M.C. for information on the patients seen at families' clinics, and to the Director General of Army Medical Services for permission to publish.

\section{REFERENCES}

Communicable Disease Reports (1974 and 1975). Public Health Laboratory Service.

BeLL, E. J. and Grist, N. R. (1970). Lancet i, 326.

Crovari, P. (1969). G. Ig. Med. prev. 10, 163.

FAULKENER, R. S. and OzERE, R. L. (1960). New Engl. J. Med. 263, 551.

Grist, N. R., BeLL, E. J. and REID, D. (1975). Scot. med. J. 20, 27.

Hughes, D. T. D., Webb, J. F., Chang, W. K. and HaRT, R. J. C. (1963). Brit. med. J. i, 649.

Ramos-Alvarez, M. and Sabin, A. B. (1958). J. Amer. med. Ass. 167, 143.

Robertson, B. (1976). J. roy. Army med. Cps. 122,

\section{Publications by Officers-1975}

The following is a list of publications by Officers, or late of, the R.A.M.C. which have appeared during 1975, other than in the Journal of the R.A.M.C.

CROWDY, J. P. Community Medicine-A Personal View. Proc. roy. Soc. Med. 68, 727-730.

CROWDY, J. P. (Sowden, R. R.) Cigarette Smoking and Respiratory Ill-Health in The British Army. Lancet i, 1232.

CROWDY, J. P. The Soldier's Food. Practitioner 212, 560-569 (1974-late receipt).

HINDSON, T. C. Irgasan a Hazard in Deodorants. Contact Dermatitis 1, 328 and Chemicals in Hair Dye-An Unusual Dental Hazard. Contact Dermatitis 1, 333.

HINDSON, T. C. (Radcliffe, G.) Ethylene Glycol a Danger in Glass Cutting. Contact Dermatitis 1, 386.

HINDSON, T. C. Eczema From a Rare Tree-Smodingium Argutum. Contact Dermatitis 1, 389.

RADCLIFFE, G. (Hindson, T. C.) Ethylene Glycol a Danger in Glass Cutting. Contact Dermatitis 1, 386.

SAYERS, M. H. P. (Cernik, A. A.) Application of Blood Cadmium Determination to Industry Using a Punched Disc Technique. Brit. J. industr. Med. 32, 155-162.

VELLA, E. E. The Development of Pathology in the R.A.M.C. Proc. roy. Soc. Med. 68, 321-326.

YOUNGSON, R. M. Anomaly in Visual Acuity Testing in Children. Brit. J. Ophthal. 59, $168-173$. 